\begin{tabular}{|c|c|c|}
\hline- & Int.J.Curr.Microbiol.App.Sci (2021) 10(08): 728-735 & \\
\hline & $\begin{array}{l}\text { International Journal of Current Microbiology and Applied Sciences } \\
\text { ISSN: 2319-7706 Volume } \mathbf{1 0} \text { Number } 08 \mathbf{( 2 0 2 1 )} \\
\text { Journal homepage: } \underline{\text { http://www.ijcmas.com }}\end{array}$ & 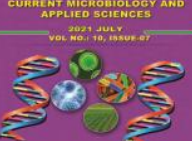 \\
\hline $\begin{array}{l}\text { EXCELLENT } \\
\text { PUBLISHERS }\end{array}$ & & \\
\hline
\end{tabular}

\title{
Entomological Surveillance of Vectors of Yellow Fever, Dengue, Chikungunya and Zika Virus at Kannur International Airport, Kerala, India
}

\author{
K. Regu, R. Rajendran*, Anila Rajendran, S. B. Anusree, \\ W. Tamizharasu and Rajesh Poduval
}

National Centre for Disease Control, Calicut-673 003, Kerala, India

*Corresponding author

\begin{tabular}{l} 
K e y w o r d s \\
$\begin{array}{l}\text { Aedes-borne } \\
\text { diseases; }\end{array}$ \\
$\begin{array}{l}\text { Entomological } \\
\text { surveillance; } \\
\text { Vector control }\end{array}$ \\
\hline Article Info \\
$\begin{array}{l}\text { Accepted: } \\
\text { 25 July 2021 } \\
\text { Available Online: } \\
\text { 10 August 2021 }\end{array}$ \\
\hline
\end{tabular}

Keywords

Aedes-borne diseases; Entomological surveillance;

Accepted:

25 July 2021

10 August 2021

\section{A B S T R A C T}

Aedes-borne diseases such as dengue, chikungunya, yellow fever, Zika virus, etc. are growing global concern due to geographic expansion of vectors and pathogens. The International Health Regulations (IHR) envisage that every international ports/airports and its adjacent areas within a perimeter of 400 meters should be kept free from Aedes mosquitoes. Kannur International Airport was opened on September 2018. Some minor construction work is in progress. In order to assess the existing situation on the prevalence and distribution of Aedes (Stegomyia) mosquitoes and control measures taken thereof, a vector survey was carried out in and around Kannur International Airport in the month of May 2019 (Pre monsoon) by National Centre for Disease Control, Calicut, Kerala branch. This is the first Entomological surveillance inside the airport since its inception. In order to find out the fluctuation of Aedes larval indices, the survey was done in November 2019 (Post monsoon) in and around the airport area. The premise index (PI)was found to be above the critical level inside the airport in both the seasons. During post monsoon, the Breteau index (BI) was found above the critical level inside the airport. However, all the Aedes larval indices were found below the critical level in the residential areas around the airport in both the seasons.

\section{Introduction}

Vector-borne diseases (VBDs) are among the most important global public health problems and are associated with serious economic burden in affected countries. VBDs occur mostly in tropical and subtropical regions and are transmitted by hematophagous arthropods and most importantly by mosquitoes. The emergence and re-emergence of VBDs during the past 50 years have been steered by population growth, unplanned urbanization, globalization, expanded conveyance facilities, etc. (WHO, 2020). 
Among the VBDs, Mosquito-borne diseases (MBDs) play a significant role in human sufferings all over the world. It is estimated that nearly 700 million people get a mosquitoborne infection resulting in over 1 million deaths annually (Caraballo and King, 2014). Mosquitoes belong to the family Culicidae and currently it includes 3,585 species (Harbach,2021), of which Aedes (Stegomyia) mosquitoes are medically important as they transmit diseases such as yellow fever (YF), dengue (DF), chikungunya (CHIK), Zika virus, etc.

Among the Aedes (Stegomyia) mosquitoes, Aedes aegypti and Aedes albopictus are two most common mosquito species across the world. This is mainly due to their capability to adapt to new environments and is capable of transmitting viruses to humans. Ae. aegypti is known to transmit viruses such as dengue, yellow fever, chikungunya and Zika.

It is considered to be a potential vector of Venezuelan Equine Encephalitis (Larsen and Ashley, 1971), and is capable of transmitting West Nile virus also (Truell, et al., 2005). Ae. aegypti proliferates in densely populated areas which lack proper water supply, waste disposal and sanitation, etc. (Honorio et al., 2009). Ae.albopictus is also playing a role as vector for the transmission of YF, DF, CHIK fever (Hochedez et al., 2006) and Usutu virus (Calzolari et al., 2012). Aedes mosquito is considered asa highly domesticated mosquito, very adapted to living with man, preferring to rest indoors and to feed on humans during day time. The Aedes mosquitoes generally breed in man-made and natural habitats seen in house/building premises (Sheela Devi et al., 2012; Rajendran et al., 2019a; Rajendran et al., 2020a; Rajendran et al., 2021a).

Dengue is one of the most prevalent viral infections transmitted by Aedes mosquitoes. Dengue fever (DF) has become a major public health concern in many parts of the world including India. Chikungunya fever (CHIKF) is a global public health concern and is caused by chikungunya virus (CHIKV).India witnessed major CHIKF outbreaks from 20052010.

After 2010, the country experienced a drastic decline in reported cases (Muniaraj, 2014). Zika, another Aedes-borne viral disease is reported from Gujarat, Tamil Nadu and recently from Rajasthan (Yadav et al., 2019).

Though most of the countries in Asia have favorable conditions for Aedes mosquito breeding and considered receptive for yellow fever (YF) transmission, the disease has never occurred in Asia. But the possibility of transmission of $\mathrm{YF}$ in Asia cannot be impeded, especially considering the rapid ingress of travelers from endemic areas (Agampodt and Wickramage, 2013).

The rapid global development of conveyance facilities accelerated the entry and establishment of Ae.aegypti and Ae.albopictus in seaports and airports and thus there exist a potential threat of disease outbreaks. To tackle the threat of global spread of vectors and VBDs and to sustain sanitary standards at international borders and points of entry (PoE), the fifty-eight World Health Assembly adopted the new International Health Regulations-IHR(WHO, 2008). The IHR anticipate that all International seaports and airports should be kept free from all types of vector mosquitoes for a distance of 400 meters around the perimeter of the ports to attain the utmost aim of public health safety. To achieve this, regular vector surveillance and suitable vector control measures should be carried out in and around the ports. Present finding recites to an assessment carried out in Kannore airport during third week of May 2019 (Pre monsoon) and last week of November 2009 (Post monsoon). 


\section{Materials and Methods}

\section{Study area}

Vector surveillance was carried out in around Kannur International Airport. It is located near Mattannur municipality in Thalassery taluk of Kannur district, Kerala state. It was opened on $9^{\text {th }}$ September 2018 and is operated by Kannur International Airport Limited (KIAL), a public-private partnership trust. The coordinates of the airport are $11.92^{\circ}$ North and $75.55^{\circ}$ East. This airport is having an area of about 2,300 acres. The airport has an integrated passenger terminal with a floor area of $97,000 \mathrm{~m}^{2}$, for both International and domestic travelers. The airport has one runway, $07 / 25$ which is 3,050 by 45 meters. The airport has aircraft maintenance, repair and overhaul unit facility and is expected to cater to both narrow and wide bodied aircrafts. The other facilities include aviation fuel farm, Indian Navy air enclave, cargo terminal complex, etc. To assess the Aedes mosquito prevalence around the airport, 100 houses were randomly selected from Mattannur municipal and Kizhellurpanchayath areas.

\section{Entomological surveillance}

Aedes surveillance was undertaken in and around Kannur International Airport during the third week of May 2019 (Pre monsoon) and last week of November 2019 (Post monsoon). Kannur airport was opened on September 2018. The Vector surveillance carried out by NCDC, Kerala branch in KIAL in May 2019 is the first of its kind since its launch. Entomological surveillance of Aedes mosquito has been standardized on different larval indices on the simple confirmation of the presence or absence of Aedes immature in each container seen in and around each house (Nagpal et al., 2016).All water holding containers seen inside the house/building (such as water stored utensils, coolers, refrigerator trays, fire extinguisher buckets, overhead tanks, cement tanks attached to bath rooms, etc.) and containers/habitats seen around the house (namely, plastic, metal, earthen containers; cement tanks, glass bottles, coconut shells, discarded tires, etc. 0 were inspected. The collected larvae were identified microscopically/after adult emergence as per guidelines (WHO, 1995).

The number of premises/houses surveyed and positive for Aedes larvae, number of containers searched and positive/house or premise was recorded in a pre designed proforma for classification. The usual methods of Aedes survey as adopted by the National Vector Borne Disease Control Program (NVBDCP) for outbreak investigations were adopted. The data on larval survey were analyzed and calculated in terms of house index/premise index (HI/PI- percentage of houses/premises positive for Aedes larvae), container index (CI-percentage of containers positive for larvae), number of positive containers per 100 houses - Breateau Index (BI).

\section{Results and Discussion}

\section{Kannur International Airport}

In operational areas of Kannur airport, a total of 14 water holding containers at 17 premises were checked in May 2019 (Pre monsoon), in which 2 containers were found positive for Aedes larvae (PI-11.76\%). The details are given in Table 1 . Of the 14 containers searched, $71.43 \%$ were plastic containers followed by earthen (21.43\%) and metal containers (7.14\%) Among these, 2 containers were found positive for Aedes larvae (CI$14.28 \%$ ) and breteau index was found to be 11.76 (Fig. 1).

In order to find out the seasonal variation of Aedes larval indices inside the airport, survey 
was done in November 2019 (Post monsoon). Of the 17 premises checked, 2 were found positive for Aedes breeding (PI- 11.76\%). A total of 35 water holding containers were examined, 4 were found positive for Aedes immatures (CI-11.42\%) and the breteau index was 23.53 (Fig.1). Of the total containers checked, $45.71 \%$ were discarded tires followed by plastic (31.43\%), metal $(22.86 \%)$ containers. Of the 4 Aedes positive containers, plastic and metal containers constitute $50 \%$ each.

\section{Residential area}

Pre monsoon Aedes surveillance in the residential areas around airport was done in 100 randomly selected houses. Inside and the surroundings of each house was closely examined for Aedes mosquito breeding, but only 4 premises were found positive for Aedes larvae/pupae (HI-4\%). A total of 35 water holding containers were seen in the survey area. Among these, 54.29\% were plastic containers followed by discarded tires (20\%), metal $(17.14 \%)$ and cement tanks $(8.57 \%)$. The details are given in Table 2. Of these, 4 containers were found positive for Aedes breeding (CI-11.4\%) and the breteau index was 4 (Fig.2).

Aedes survey was done in 100 randomly selected houses around the airport in November 2019 (Post monsoon), of which 6 were found positive for Aedes breeding (HI$6 \%$ ). A total of 71 containers with water were checked and 7 were with Aedes larvae (CI$9.85 \%)$. Most of the containers were plastic $(47.89 \%)$ followed by used tires $(23.94 \%)$, earthen $(11.27 \%)$, metal $(9.86 \%)$ and cement tanks $(7.04 \%)$. Aedes larvae could be seen in plastic (3), metal (2), and one each for earthen and used tires. The breteau index (BI) was 7.0 (Fig.2). The adult mosquitoes reared from the larvae/pupae collected from inside and around (residential area) airport during both the seasons were identified as Ae.albopictus. Mosquito-borne viruses have become significant public health problems, with the emergence and re-emergence of Aedes-borne diseases (ABDs) nearly worldwide. The emergence and re-emergence of $\mathrm{ABDs}$ is associated with complex factors, such as viral recombination and mutation, leading to more virulent and adaptive strains, unplanned urbanization, expanded conveyance facilities and human interferences creating more conducive environment for vector-host interaction. In addition to this, global warming increases vector distribution and transmission dynamics of arboviral diseases.

Generally, House index/Premise index (HI/PI) $>10 \%$ and Breteau index (BI) $>20$ are considered as critical. Vector surveillance in the residential areas around the airport showed that the aforesaid Aedes larval indices were below the critical level in both the seasons. Every year the District health authorities are giving warning to the public on impending outbreak of mosquito-borne infectious diseases and the need to observe 'pre monsoon drive' by cleaning the surroundings of the houses/shops/office buildings, etc. to avoid mosquito breeding. It seems that the local health workers and local bodies of Mattannur municipality and Kizhellur panchayath are actively involved in source reduction activities with the support of local inhabitants. The comparatively low level of Aedes larval indices in the residential areas in the aforesaid areas in both the seasons credited to the persistent vector control activities.

However, the premise index (PI) inside the airport in both the seasons and breteau index (BI) in post monsoon season was found above the critical level. This necessitates the need for regular vector surveillance and proper vector control activities under trained man power. 
Table.1 Surveillance of Aedes mosquitoes at Kannur International airport in 2019

\begin{tabular}{|c|c|c|c|c|c|c|c|c|c|c|c|c|c|}
\hline \multirow[t]{3}{*}{ Sl.No. } & \multirow[t]{3}{*}{ Premises } & \multicolumn{6}{|c|}{ Pre monsoon } & \multicolumn{6}{|c|}{ Post monsoon } \\
\hline & & \multicolumn{2}{|c|}{ Plastic } & \multicolumn{2}{|c|}{ Metal } & \multicolumn{2}{|c|}{ Earthen } & \multicolumn{2}{|c|}{ Plastic } & \multicolumn{2}{|c|}{ Metal } & \multicolumn{2}{|c|}{ Tires } \\
\hline & & $\mathrm{S}$ & $\mathrm{P}$ & $\mathrm{S}$ & $\mathrm{P}$ & $\mathrm{S}$ & $\mathrm{P}$ & S & $\mathrm{P}$ & S & $\mathrm{P}$ & $\mathrm{S}$ & $\mathrm{P}$ \\
\hline 1 & IA Terminal & - & - & - & - & - & - & - & & - & - & - & - \\
\hline 2 & $\begin{array}{c}\text { Ground handling Parking } \\
\text { area }\end{array}$ & - & & - & & - & & 4 & - & 2 & - & - & \\
\hline 3 & Air India Workshop & - & - & - & - & - & - & - & - & - & - & - & - \\
\hline 4 & Fire station East & - & - & 1 & 1 & 1 & - & 3 & - & 2 & - & - & - \\
\hline 5 & AGL Substation East & - & - & - & - & - & - & - & - & - & - & - & - \\
\hline 6 & Perimeter area & - & - & - & - & - & - & - & - & - & - & - & - \\
\hline 7 & Fire Drill pit & & - & - & - & - & - & - & - & - & - & - & - \\
\hline 8 & Fire Station West & 1 & - & - & - & - & - & - & - & - & - & - & - \\
\hline 9 & ATC & - & - & - & - & - & - & 1 & - & 1 & - & 1 & - \\
\hline 10 & Restaurant and canteen & - & - & - & - & - & - & 1 & - & - & - & - & - \\
\hline 11 & AGL Substation West & - & - & - & - & - & - & 1 & 1 & & - & - & - \\
\hline 12 & $\begin{array}{l}\text { BharathPetoleum } \\
\text { Company }\end{array}$ & - & - & - & - & - & - & 1 & 1 & 3 & 2 & 15 & - \\
\hline 13 & Baggage break up area & - & - & - & - & - & - & - & - & - & - & - & - \\
\hline 14 & $\begin{array}{l}\text { Passenger boarding } \\
\text { bridge }\end{array}$ & 1 & - & - & - & - & - & - & - & - & - & - & - \\
\hline 15 & Reserved lounge I & 5 & - & - & - & 1 & - & - & - & - & - & - & - \\
\hline 16 & Reserved lounge II & 3 & - & - & - & - & - & - & - & - & - & - & - \\
\hline 17 & AC cooling tower & - & - & - & - & 1 & 1 & - & - & - & - & - & - \\
\hline & Total & 10 & - & 1 & 1 & 3 & 1 & 11 & 2 & 8 & 2 & 16 & - \\
\hline
\end{tabular}

Fig.1

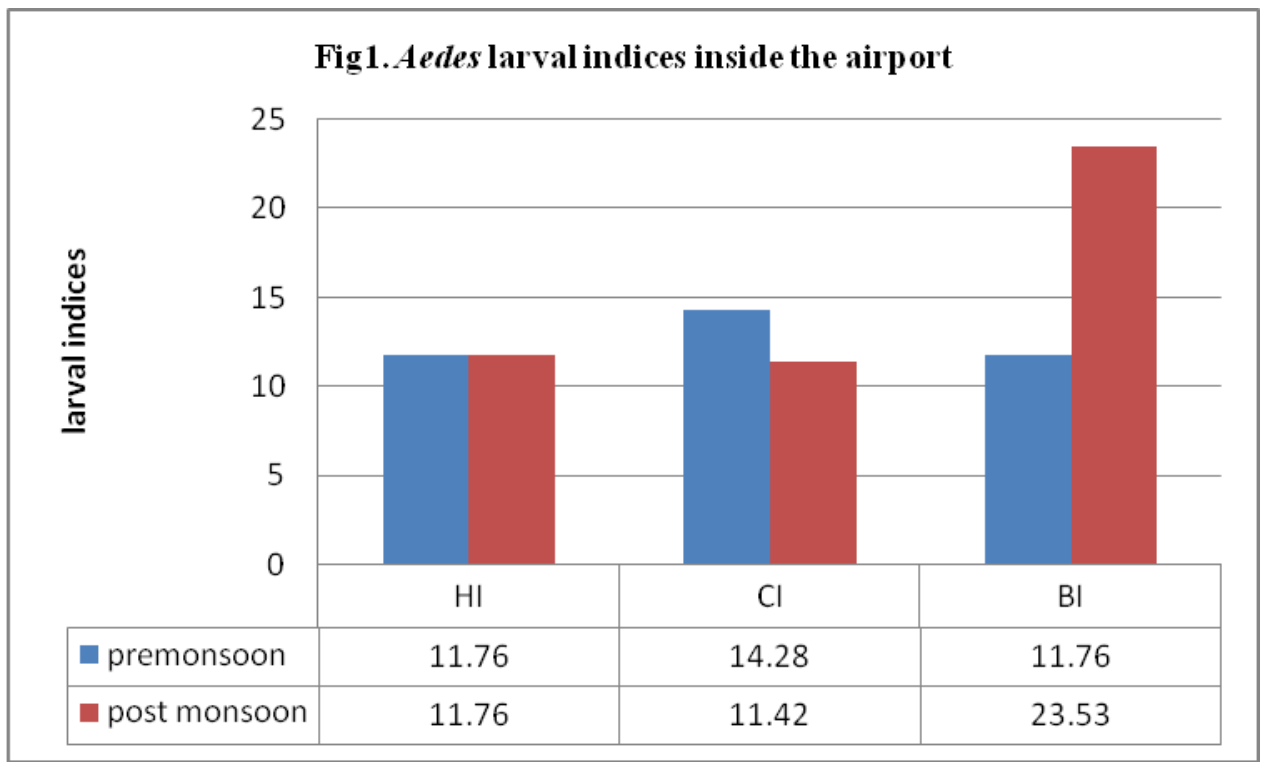


Fig.2

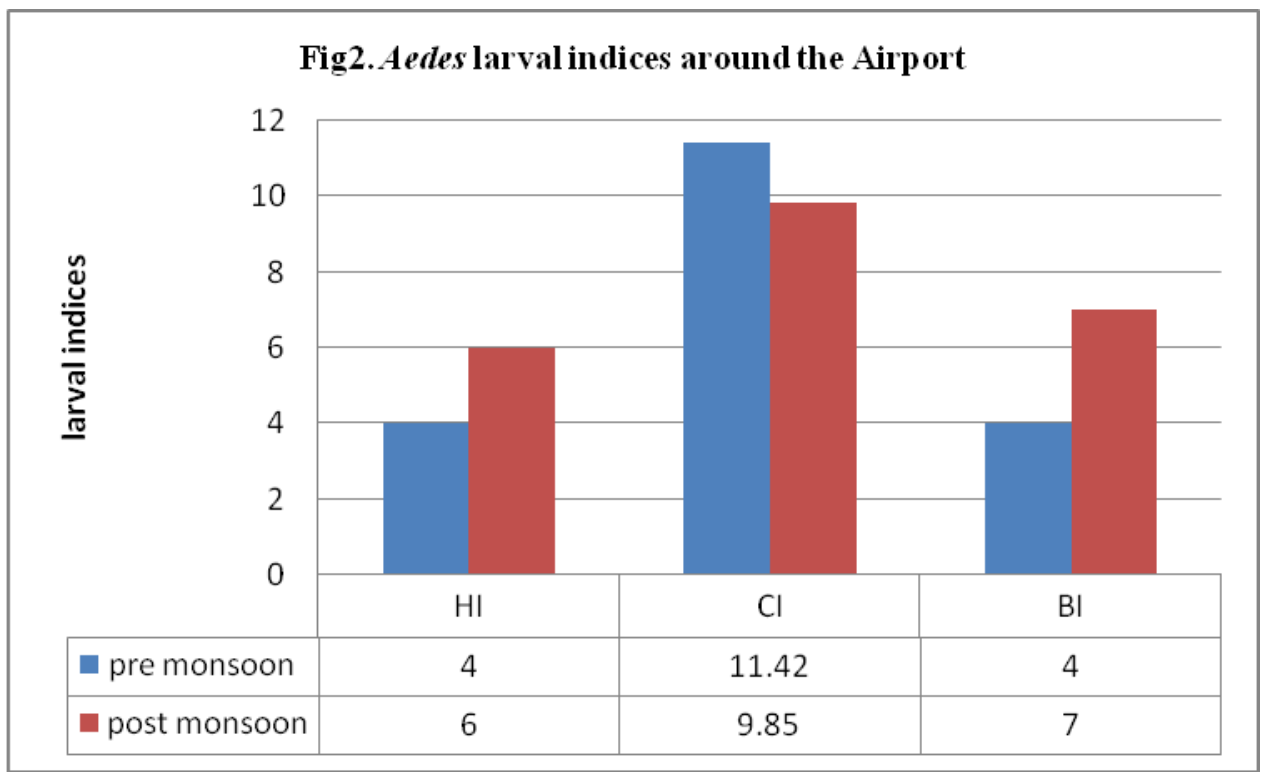

The Kannur International airport is commissioned on September 2018. This is the first Entomological survey done in the airport since its inception. Airport Health Officer (APHO) and trained man power for supervision and conduct of the survey is essential. The surveillance of Aedes mosquitoes in and around Cochin International Airport during 2013 to 2019 showed no Aedes larval positivity inside the airport during 2014, 2016, 2018 and 2019. In rest of the years the larval positivity was below the critical level (Rajendran, et al., 2020b). A study related to the vectors of YF, DF, CHIK and Zika in New Mangalare sea port showed high level of breteau index (BI) in post monsoon season inside the port area (Rajendran, et al., 2021b). However no Aedes larval positivity could be noted in a study conducted in pre monsoon of 2018 in the same seaport (Rajendran, et al., 2019b).The high level of PI and BI observed in the present study is mainly due to the availability of breeding habitats in the air port premises during pre monsoon and post monsoon which is mainly due to summer rain and monsoon rain respectively. This in turn facilitates the breeding of Aedes mosquitoes. The main intention of International Health Regulations (IHR) is to sustain vector free status at airports/seaports through planned vector surveillance and vector control measures.

Thus the impending threat on disease outbreaks can be reduced in and around the airports by preventing the entry and establishment of vectors and pathogens.

Hence a careful observance in and around international airports, seaports and ground crossings by vector control experts is needed to pinpoint the factors responsible for the establishment of disease vectors and impose bio-security and quarantine measures to avert global health risks (Kaul et al., 1998).

\section{Acknowledgement}

The authors are grateful to the Director, NCDC, Delhi for providing opportunity to undertake the survey in Kannur International airport. Thanks to Shri. Sajeev, Airport Manager and Smt. Reshmi, Junior Assistant for the support to carry out the work inside the airport. Thanks to Sh. N.B. Narayana, Laboratory Assistant, Sh. V.R. Rajesh, 
Laboratory Assistant, Sh. S. Sunil Kumar, field worker, NCDC, Calicut for their technical assistance.

\section{References}

Agampodt, S. B., and Wickramage, K., 2013. Is there Yellow fever virus Transmission in South Asian Countries with Hyperendemic Dengue? BioMed Research International. Article ID 905043, 9 pages.

Calzolari, M., Gaibani,P., Bellini, R., Defilippo, F., Pierro, A., Albieri, A., Maioli, G., Luppi, A., Rossin, G., Balzani, A., Tamba, M., Galletti, G., Galati, A., Carrieri, M., pogolayen, G., Cavrini, F., Natalini, S., Dottori, M., Sambri, V., Angelini, P., Bonilauri, P. 2012. Mosquito, bird and human surveillance of West Nile and Usutu viruses in Emilia - Romananga Region (Italy) in 2010. Plos One.7 (5):e38058.

Caraballo, H and King, K., 2014. Emergency department management of mosquitoborne illness: malaria, dengue, and west Nile Virus. Emergency Medicine Practice. 16(15):1-23

Harbach, R. E. 2021. Mosquito Taxonomic Inventory, Valid species, http://mosquito-taxonomic inventory.info/accessed on 5 July 2021.

Hochedez, P., Jaureguiberry, S., Debruyne, M., Bossi, P., Haufater, P., Brucker, G., Bricaire, F., and Caumes, E. 2006. Chikungunya infection in Travelers. Emerging Infectious Diseases.12(10):1565-1567.

Honorio, N. A., Codeco, C. T., Alves, F. C., Magalhaes, M. A., Lourenco-DeOliveira, R. 2009. Temporal distribution of Aedes aegypti in different districts of Rio de Janerio, Brazil, measured by two types of traps. Journal of Medical Entomology.
46(5):1001-04.

Kaul, S. M., Sharma, R. S., Sharma, S. N., Panigrahi, N., Phukan, P. K., Lal, S. 1998. Preventing dengue/dengue hemorrhagic fever outbreaks in the National Territory of Delhi- the role of entomological surveillance.Journal of Communicables Diseases. 50(3):18792.

Larsen, J. R., Ashley, R. F. 1971. Demonstration of Venezuelan equine encephalomyelitis virus in tissue of Aedes aegypti. American Journal of Tropical Medicine and Hygiene. 20(5):754-60.

Muniaraj, M. 2014. Fading chikungunya fever from India: beginning of the end of another episode? Indian Journal of Medical Research.139:468-470.

Nagpal, B. N., Gupta, S. K., Shamin, A., Vikram, K., Srivastava, A., Tuli, N. R., Saxena, R., Singh, H., singh, V. P., Bhagat, V. N., Yadav, N. K., Valecha, N. 2016. Control of Aedes aegypti breeding : a novel intervention for prevention and control of dengue in an endemic zone of Delhi, India. PLos One.11 (12):e0166768.

Rajendran, R., Anusree, S. B and Regu, K. 2019a. Seasonal variation and breeding of Aedes albopictus in one of the coastal districts of Kerala. International Journal of Mosquito Research, 7(4):78-82.

Rajendran, R., Regu, K., and Kurian, J. M. 2019b. Monitoring global public health threat- Surveillance of Aedes (Stegomyia) mosquitoes in New Mangalore sea port, India. Entomon. 44(1):15-22.

Rajendran, R., Anusree, S. B., Ramachandran, K. and Regu, K. 2020a. Pre Intervention Situation Analysis on Control of Vector-borne Diseases in an urban area in Kerala. Journal of Emerging Technologies and 
Innovative Research, 7(5): 592-600.

Rajendran, R., Regu, K., Anusree, S. B. Tamizharasu, W and Rajendran, A. 2020b. Surveillance of Aedes (Stegomyia) mosquitoes in and around International Airport, KeralaAssessment of vector control efforts. Entomon, 45(2):135-142.

Rajendran, R., Karmakar, S. R., VinayGarg, Rajlakshmi Viswanathan, Kamran Zaman, Anusree, S. B and Regu, K.2021a. An appraisal of post flood dengue vector Aedes albopictus Skuse (Diptera: Culicidae) surveillance in a coastal district of Kerala, India. Entomon,46(1):25-32.

Rajendran, R., Regu, K., Anusree, S. B., Rajendran, A and Tamizharasu, W. 2021b. Seasonal surveillance of the vectors of yellow fever, dengue, chikungunya and Zika in New Mangalore Sea Port, India. International Journal of Mosquito Research, 8(3):47-50.

Sheela Devi. D., Rajendran, R., and Somashekaran Pillai. 2012. Diversity of Aedes larval habitats in rural and urban areas of Malappuram district.
Entomon, 37(1-4): 31-39.

Truell, M. J., Dohm, D. J., Sardelis, M. R., Oguinn, M. L., Andreadis, T. G., Blow, J. A. 2005. An update on the potential of north American mosquitoes (Diptera:Culicidae) to transmit West Nile virus. Journal of Medical Entomology, 42(1):57-62.

WHO, 1995. Guidelines for Dengue surveillance and mosquito control, Western Pacific Education in action series, 8:1-104.

WHO, 2008.International Health regulations 2005, World Health Organization, $2^{\text {nd }}$ edition, http://www.who.int/csr/ihr/IHR-2005en.pdf.

WHO, 2020. Vector-borne diseases, Key facts, 2 March 2020.

Yadav, P. D., Malhotra, B., Sapkal, G., Nyayanit, D. A., Deshpande, G., Gupta, N., Padinjaremattathil, U. T., Sharma, H., Sahay, R. R., Sharma, P., Mourya D. T. 2019. Zika virus outbreak in Rajasthan, India in 2018 was caused by a virus endemic to Asia. Infect. Genet. Evol. 69:199-202.

\section{How to cite this article:}

Regu, K., R. Rajendran, Anila Rajendran, S. B. Anusree, W. Tamizharasu and Rajesh Poduval. 2021. Entomological Surveillance of Vectors of Yellow Fever, Dengue, Chikungunya and Zika Virus at Kannur International Airport, Kerala, India. Int.J.Curr.Microbiol.App.Sci. 10(08): 728735. doi: https://doi.org/10.20546/ijcmas.2021.1008.081 